\title{
Analysis of caesarean section rate according to modified Robson's classification at tertiary care centre in Uttarakhand, India
}

\author{
Kusum Dogra*, Neetu Arora, Bhawna Sharma, Meenakshi Tanwar
}

\begin{abstract}
Department of Obstetrics and Gynecology, Shri Guru Ram Rai Institute of Medical Health and Sciences, SMIH, Patel
\end{abstract} Nagar, Dehradun, Uttarakhand, India

Received: 26 February 2019

Accepted: 15 March 2019

\section{*Correspondence:}

Dr. Kusum Dogra,

E-mail: drkusumdogra@gmail.com

Copyright: () the author(s), publisher and licensee Medip Academy. This is an open-access article distributed under the terms of the Creative Commons Attribution Non-Commercial License, which permits unrestricted non-commercial use, distribution, and reproduction in any medium, provided the original work is properly cited.

\begin{abstract}
Background: High caesarean section rate worldwide including India is matter of concern. The aim of this study is to analyse caesarean section rate at tertiary care centre according to Modified Robson's classification.

Methods: This retrospective study was conducted at Shri Guru Ram Rai Institute of Medical and Health Sciences (SGRRIMHS) and Shri Mahant Indiresh Hospital at Dehradun from April 2018 to September 2018. All women delivered during this period were classified according to modified Robson's classification using their maternal characteristics and obstetric history. For each group, authors calculated the caesarean section rate within the group and its contribution to overall caesarean section rate.

Results: Out of total 1302 women delivered, 395 underwent CS (30.3\%). The major contribution to overall caesarean section rate was $33.4 \%$ by group 5 (Previous CS, singleton, cephalic, >37weeks) followed by $16.7 \%$ by group 1 (nullipara, singleton, cephalic, >37 weeks, spontaneous labour), 12.4\% by group 3 ( multipara, singleton, cephalic, $>37$ weeks, spontaneous labour ).CS rates among various group ranges from $100 \%$ among women with abnormal lie (group 9) to $77.5 \%$ in nulliparous breech (group 6), $73.7 \%$ in previous CS (group 5) and least $11.2 \%$ in multipara induced or pre labour CS (group 4).

Conclusions: Modified Robson classification is simple, systematic, reproducible and can be effectively utilized in analyzing delivering women. Major contribution to overall caesarean section is made by previous CS.
\end{abstract}

Keywords: Caesarean section, High caesarean, Modified Robson’s classification

\section{INTRODUCTION}

Ever since caesarean section has been introduced in obstetrical practice, it had revolutionized the modern obstetrical practice as many difficult instrumental delivery like midcavity forceps and abnormal vaginal delivery are obsolete now. But like any surgical interventions, it has its merits and demerits. For past few years there has been increased incidence of placenta previa, placenta accrete syndrome, risk of rupture uterus in previous CS. High caesarean birth rates are an issue of international public health concern. ${ }^{1}$ In 1985, WHO (World Health Organisation) proposed the ideal rate of caesarean section between $10-15 \% .^{2}$ In India CS rates is increasing steadily and there is wide variation in CS rates between private and public health sector. ${ }^{3,4}$ Thus, need arises to focus on contributors and develop strategies to avoid unnecessary caesarean sections. There is need for an internationally accepted classification system for caesarean section that would allow meaningful and relevant comparison of CS rates. The Robson classification is an objective tool recommended by WHO to achieve this goal. Robson proposed a new classification system, the Robson ten group classification system to allow critical analysis according to characteristics of pregnancy. ${ }^{5}$ 
Table 1: Modified Robson's classification.

\begin{tabular}{|c|c|}
\hline Major group & Subgroup \\
\hline \multicolumn{2}{|l|}{$\begin{array}{l}\text { Nullipara, singleton cephalic, } \geq 37 \\
\text { weeks, spontaneous labour }\end{array}$} \\
\hline $\begin{array}{l}\text { Nullipara, singleton cephalic, } \geq 37 \\
\text { weeks }\end{array}$ & $\begin{array}{l}\text { Induced } \\
\text { Caesarean } \\
\text { section before } \\
\text { labour }\end{array}$ \\
\hline \multicolumn{2}{|l|}{$\begin{array}{l}\text { Multipara, singleton cephalic, } \geq 37 \\
\text { weeks, spontaneous labour }\end{array}$} \\
\hline \multirow[b]{2}{*}{$\begin{array}{l}\text { Multipara, singleton cephalic, } \geq 37 \\
\text { weeks }\end{array}$} & Induced \\
\hline & $\begin{array}{l}\text { Caesarean } \\
\text { section before } \\
\text { labour }\end{array}$ \\
\hline \multirow{3}{*}{$\begin{array}{l}\text { Previous Caesarean section, } \\
\text { singleton cephalic, } \geq 37 \text { weeks }\end{array}$} & $\begin{array}{l}\text { Spontaneous } \\
\text { labour }\end{array}$ \\
\hline & Induced labour \\
\hline & $\begin{array}{l}\text { Caesarean } \\
\text { section before } \\
\text { labour }\end{array}$ \\
\hline \multirow{3}{*}{ All nulliparous breeches } & $\begin{array}{l}\text { Spontaneous } \\
\text { labour }\end{array}$ \\
\hline & Induced labour \\
\hline & $\begin{array}{l}\text { Caesarean } \\
\text { section before } \\
\text { labour }\end{array}$ \\
\hline \multirow{3}{*}{$\begin{array}{l}\text { All multiparous breeches(including } \\
\text { previous Caesarean section) }\end{array}$} & $\begin{array}{l}\text { Spontaneous } \\
\text { labour }\end{array}$ \\
\hline & Induced labour \\
\hline & $\begin{array}{l}\text { Caesarean } \\
\text { section before } \\
\text { labour }\end{array}$ \\
\hline \multirow{3}{*}{$\begin{array}{l}\text { All multiple pregnancies (including } \\
\text { previous Caesarean section) }\end{array}$} & $\begin{array}{l}\text { Spontaneous } \\
\text { labour }\end{array}$ \\
\hline & Induced labour \\
\hline & $\begin{array}{l}\text { Caesarean } \\
\text { section before } \\
\text { labour }\end{array}$ \\
\hline \multirow{3}{*}{$\begin{array}{l}\text { All abnormal lies(including } \\
\text { previous Caesarean section but } \\
\text { excluding breech) }\end{array}$} & $\begin{array}{l}\text { Spontaneous } \\
\text { labour }\end{array}$ \\
\hline & Induced labour \\
\hline & $\begin{array}{l}\text { Caesarean } \\
\text { Section before } \\
\text { labour }\end{array}$ \\
\hline \multirow{3}{*}{$\begin{array}{l}\text { All singleton cephalic, } \leq 36 \text { weeks } \\
\text { (including previous Caesarean } \\
\text { section) }\end{array}$} & $\begin{array}{l}\text { Spontaneous } \\
\text { labour }\end{array}$ \\
\hline & Induced labour \\
\hline & $\begin{array}{l}\text { Caesarean } \\
\text { section before } \\
\text { labour }\end{array}$ \\
\hline
\end{tabular}

The characteristics used are:

- Single or multiple pregnancy

- Nulliparous, multiparous, or multiparous with a previous CS

- Cephalic, breech presentation or other mal presentation
- Spontaneous or induced labour

- Term or preterm births.

This classification has been widely used in various countries. It consists of 10 patient population categories that are mutually exclusive. A modification to the Robson criteria has been proposed by SOGC Committee (Society of Obstetricians and Gynecologist of Canada) which enable better comparison for CS rates. This modification includes sub classification of woman having caesarean section after spontaneous onset of labour, after induction of labour and before labour. ${ }^{6}$ Though there have been limitation to this modification also, still it is simple, easily implementable and a robust tool to monitor Caesarean Section rates (Table 1).The aim of this study was to analyze Caesarean section rates at a tertiary care centre in Uttarakhand by using Modified Robson's classification.

\section{METHODS}

This retrospective study was conducted in the Department of Obstetrics and Gynecology at SGRRIMHS and SMIH, Dehradun from April 2018 to September 2018.All women who delivered during this period were included except women with gestational age less than 20 weeks and who delivered fetus less than 500 grams ( $2^{\text {nd }}$ trimester abortion were excluded). Relevant obstetric data was collected from labour room delivery register like gestational age, parity, number of fetuses, presentation of fetus, whether patient presented with spontaneous labour or was induced. Women were classified according to Modified Robson classification. For each group, authors calculated and analyzed the Caesarean Section rate within the group and its contribution to overall CS rate.

\section{RESULTS}

A total 1302 women delivered in our institute from April 2018 to September 2018. All women who delivered were classified according to Modified Robson's classification. Out of 1302 women 935 underwent caesarean section. So caesarean section rate in present study was $30.3 \%$ (Table 2).

Maximum number of women 263 (20.2\%) women were in group 1 followed by $258(19.8 \%)$ women in group 3, then $226(17.4 \%)$ women in group 2 whereas group 5 consist of $179(13.7 \%)$ women. Least number of women $7(0.5 \%)$ were in group 9 (Table 3). Caesarean section rate within the group ranges between $100 \%$ in group 9 (singleton, transverse or oblique lie) to $77.5 \%$ in group 6 (Nulliparous, singleton, breech) followed by $73.7 \%$ in group 5 (previous caesarean section, singleton, cephalic, term). Minimum caesarean section rate $11.1 \%$ was in group 4 (Multiparous excluding previous CS, single, cephalic, term, induced or CS before labour) (Table 3). 
Table 2: Classification of women as per modified Robson's classification.

\begin{tabular}{|c|c|c|c|c|c|c|}
\hline Major group & Subgroup & $\begin{array}{l}\text { No. of } \\
\text { women } \\
\text { in the } \\
\text { group } \\
\text { (a) }\end{array}$ & $\begin{array}{l}\text { Relative } \\
\text { size of } \\
\text { the } \\
\text { group } \\
\text { (b) }\end{array}$ & $\begin{array}{l}\text { No. } \\
\text { of } \\
\text { CS } \\
\text { (c) }\end{array}$ & $\begin{array}{l}\text { CS rate } \\
\text { in the } \\
\text { group } \\
\text { (d) }\end{array}$ & $\begin{array}{l}\text { Contribution } \\
\text { made by the } \\
\text { group to overall } \\
\text { CS rate(e) }\end{array}$ \\
\hline $\begin{array}{l}\text { Nullipara, singleton cephalic, } \geq 37 \\
\text { weeks, spontaneous labour }\end{array}$ & & 263 & 20.2 & 66 & 25.1 & 16.7 \\
\hline \multirow{2}{*}{$\begin{array}{l}\text { Nullipara, singleton cephalic, } \geq 37 \\
\text { weeks }\end{array}$} & Induced & 206 & 15.8 & 29 & 14.1 & 7.3 \\
\hline & $\begin{array}{l}\text { CS before } \\
\text { labour }\end{array}$ & 20 & 1.5 & 20 & 100 & 5.1 \\
\hline $\begin{array}{l}\text { Multipara, singleton cephalic, } \geq 37 \\
\text { weeks, spontaneous labour }\end{array}$ & & 258 & 19.8 & 33 & 12.8 & 8.4 \\
\hline \multirow[b]{2}{*}{$\begin{array}{l}\text { Multipara, singleton cephalic, } \geq 37 \\
\text { weeks }\end{array}$} & Induced & 125 & 9.6 & 6 & 4.8 & 1.5 \\
\hline & $\begin{array}{l}\text { CS before } \\
\text { labour }\end{array}$ & 9 & 0.7 & 9 & 100 & 2.3 \\
\hline \multirow{3}{*}{$\begin{array}{l}\text { Previous Caesarean section, singleton } \\
\text { cephalic, } \geq 37 \text { weeks }\end{array}$} & $\begin{array}{l}\text { Spontaneous } \\
\text { labour }\end{array}$ & 66 & 5.1 & 24 & 36.4 & 6.1 \\
\hline & $\begin{array}{l}\text { Induced } \\
\text { labour }\end{array}$ & 16 & 1.2 & 11 & 68.8 & 2.8 \\
\hline & $\begin{array}{l}\text { CS before } \\
\text { labour }\end{array}$ & 97 & 7.5 & 97 & 100 & 24.6 \\
\hline \multirow{3}{*}{ All nulliparous breeches } & $\begin{array}{l}\text { Spontaneous } \\
\text { labour }\end{array}$ & 17 & 1.3 & 8 & 47.1 & 2 \\
\hline & $\begin{array}{l}\text { Induced } \\
\text { labour }\end{array}$ & 0 & 0 & 0 & 0 & 0 \\
\hline & $\begin{array}{l}\text { CS before } \\
\text { labour }\end{array}$ & 23 & 1.8 & 23 & 100 & 5.8 \\
\hline \multirow{3}{*}{$\begin{array}{l}\text { All multiparous breeches(including } \\
\text { previous Caesarean section) }\end{array}$} & $\begin{array}{l}\text { Spontaneous } \\
\text { labour }\end{array}$ & 14 & 1 & 8 & 57.1 & 2 \\
\hline & $\begin{array}{l}\text { Induced } \\
\text { labour }\end{array}$ & 4 & 0.3 & 0 & 0 & 0 \\
\hline & $\begin{array}{l}\text { CS before } \\
\text { labour }\end{array}$ & 12 & 0.9 & 12 & 100 & 3 \\
\hline \multirow{3}{*}{$\begin{array}{l}\text { All multiple pregnancies(including } \\
\text { previous Caesarean section) }\end{array}$} & $\begin{array}{l}\text { Spontaneous } \\
\text { labour }\end{array}$ & 17 & 1.3 & 7 & 41.2 & 1.8 \\
\hline & $\begin{array}{l}\text { Induced } \\
\text { labour }\end{array}$ & 2 & 0.15 & 0 & 0 & 0 \\
\hline & $\begin{array}{l}\text { CS before } \\
\text { labour }\end{array}$ & 9 & 0.7 & 9 & 100 & 2.3 \\
\hline \multirow{3}{*}{$\begin{array}{l}\text { All abnormal lies(including previous } \\
\text { Caesarean section but excluding } \\
\text { breech) }\end{array}$} & $\begin{array}{l}\text { Spontaneous } \\
\text { labour }\end{array}$ & 4 & 0.3 & 4 & 100 & 1 \\
\hline & $\begin{array}{l}\text { Induced } \\
\text { labour }\end{array}$ & 1 & 0.1 & 1 & 100 & 0.25 \\
\hline & $\begin{array}{l}\text { CS before } \\
\text { labour }\end{array}$ & 2 & 0.2 & 2 & 100 & 0.5 \\
\hline \multirow{3}{*}{$\begin{array}{l}\text { All singleton cephalic, } \leq 36 \\
\text { weeks(including previous Caesarean } \\
\text { section) }\end{array}$} & $\begin{array}{l}\text { Spontaneous } \\
\text { labour }\end{array}$ & 57 & 4.4 & 6 & 10.5 & 1.5 \\
\hline & $\begin{array}{l}\text { Induced } \\
\text { labour }\end{array}$ & 61 & 4.7 & 1 & 0.0001 & 0.25 \\
\hline & $\begin{array}{l}\text { CS before } \\
\text { labour }\end{array}$ & 19 & 1.5 & 19 & 100 & 4.8 \\
\hline Total & & 1302 & $100 \%$ & 395 & & $100 \%$ \\
\hline
\end{tabular}

Major contributor to overall CS rates were group 5 $(33.4 \%)$ followed by group $1(16.7 \%)$ then group 2
(12.4\%), group $3(8.35 \%)$ then group $6(7.8 \%)$ (Table 3 ) whereas major contributor to overall $\mathrm{CS}$ rates among 
subgroup were 5c (24.6\%) followed by group $1(16.7 \%)$ then group $3(8.4 \%)$ and group $2 \mathrm{a}(7.3 \%)$.

Group 5 comprises of 179 women which consist of $13.7 \%$ of all deliveries. Repeat CS were done in 132 patients. Sixty-six women went into spontaneous labour but required repeat CS in 24 women, 16 were induced out of which 11 underwent repeat CS whereas 97 underwent repeat CS before labour.CS rate in this group was $73.7 \%$. VBAC was $26.25 \%$.

Table 3: Robson's classification.

\begin{tabular}{|c|c|c|c|c|c|}
\hline Major group & $\begin{array}{l}\text { No. of } \\
\text { women } \\
\text { in the } \\
\text { group } \\
\text { (a) }\end{array}$ & $\begin{array}{l}\text { Relative size } \\
\text { of the group } \\
\text { (b) }\end{array}$ & $\begin{array}{l}\text { No. of } \\
\text { CS (c) }\end{array}$ & $\begin{array}{l}\text { CS rate in } \\
\text { the group } \\
\text { (d) }\end{array}$ & $\begin{array}{l}\text { Contribution } \\
\text { made by the } \\
\text { group to overall } \\
\text { CS rate(e) }\end{array}$ \\
\hline $\begin{array}{l}\text { Nullipara, singleton cephalic, } \geq 37 \text { weeks, } \\
\text { spontaneous labour }\end{array}$ & 263 & 20.2 & 66 & 25.1 & 16.7 \\
\hline $\begin{array}{l}\text { Nulliparous, single cephalic, >37 weeks, } \\
\text { induced or CS before labor }\end{array}$ & 226 & 17.4 & 49 & 21.7 & 12.4 \\
\hline $\begin{array}{l}\text { Multipara, singleton cephalic, } \geq 37 \text { weeks, } \\
\text { spontaneous labour }\end{array}$ & 258 & 19.8 & 33 & 12.8 & 8.35 \\
\hline $\begin{array}{l}\text { Multiparous (excluding previous CS), } \\
\text { single cephalic, > } 37 \text { weeks, induced or CS } \\
\text { before labor }\end{array}$ & 134 & 10.3 & 15 & 11.2 & 3.8 \\
\hline $\begin{array}{l}\text { Previous Caesarean section, singleton } \\
\text { cephalic, } \geq 37 \text { weeks }\end{array}$ & 179 & 13.7 & 132 & 73.7 & 33.4 \\
\hline All nulliparous breeches & 40 & 3.1 & 31 & 77.5 & 7.8 \\
\hline $\begin{array}{l}\text { All multiparous breeches(including } \\
\text { previous Caesarean section) }\end{array}$ & 30 & 2.3 & 20 & 66.7 & 5.1 \\
\hline $\begin{array}{l}\text { All multiple pregnancies(including } \\
\text { previous Caesarean section) }\end{array}$ & 28 & 2.2 & 16 & 57.1 & 4.05 \\
\hline $\begin{array}{l}\text { All abnormal lies(including previous } \\
\text { Caesarean section but excluding breech) }\end{array}$ & 7 & 0.5 & 7 & 100 & 1.8 \\
\hline $\begin{array}{l}\text { All singleton cephalic, } \leq 36 \\
\text { weeks(including previous Caesarean } \\
\text { section) }\end{array}$ & 137 & 10.5 & 26 & 19 & 6.6 \\
\hline Total & 1302 & $100 \%$ & 395 & & $100 \%$ \\
\hline
\end{tabular}

\section{DISCUSSION}

WHO has proposed the Robson's ten group classification system as a global standard for assessing, monitoring and comparing CS rates within and between healthcare facilities in 2015 based on two multi country surveys. ${ }^{5,7}$ Several modification of original Robson classification has been tried. Authors have used the modified Robson classification used in Canada as suggested by SOGC committee (Table 1). Jacob KJ et al has proposed TMC modified Robson's classification where total number of groups were reduced to 8 instead of 10 and each group were sub divided into 3 groups. $^{8}$

- Spontaneous

- Induced

- CS before labour.
Also, previous CS originally distributed in variety of group was made a separate group, so that Primary CS rate as well as repeat $\mathrm{CS}$ rate and VBAC rate could be calculated. Dr Prameela RC et al9 have suggested modification where group 3 and 4 were subdivided based on indications for CS. ${ }^{9}$ In present study, caesarean section rate was $30.3 \%$. Major contribution to overall CS is by group 5 (previous CS, singleton, term, cephalic) followed by group 1 (nullipara, singleton cephalic, term, spontaneous labour) then by group 3 (multipara, singleton cephalic, term, spontaneous labour (Table 3). Major contributor to primary CS rate was by group 1 followed by group 3 and then by group $2 \mathrm{a}$ (Table 2). Similar findings were noted by Kazmi $\mathrm{T}$ et al, Helena et al and Tanaka et al. ${ }^{10-12}$ Group 1 and 2 accounted for $37.5 \%$ of all the deliveries and CS rate in group 1 was $25 \%$ whereas CS rate in group 2a was $14 \%$ (Table 2). This was in accordance with study done in other parts of India by 
Shirsath A (19.6\%) and Kansara Vijay14 (20.1\%). Group 3 and 4 accounted for $30.1 \%$ of all deliveries(Table 3$){ }^{13}$ CS rate in group 3 was $12.8 \%$ which was quite higher as compared to Shirsath A $(4.8 \%)$ and Kansara V (5.4\%) and in group 4 was $11.2 \%$ which is higher than study conducted by Shrisath A $(6.6 \%) .{ }^{13,14}$ Most likely cause of increase in this group are increase in maternal age and pre pregnancy BMI, changes in obstetric practice like widespread use of electronic fetal monitoring, induction of labour, epidural analgesia, reduce use of mid cavity forceps, on demand CS and fear of litigation among health care providers. Group 5 (Previous CS, singleton, cephalic, term) comprises of $13.7 \%$ of all deliveries and CS rate in this group was $73.7 \%$ (Table 3) which was slightly lower than that of Shrisath A (87.2\%) and Kansara Vijay (98.3\%) whereas CS rate in sub group 5a, $5 \mathrm{~b}$ were $36.6 \%$ and $68.75 \%$ (Table 2). ${ }^{13,14}$

Previous CS who presented with spontaneous labour had more successful VBAC (Vaginal Birth After Caesarean) than patients who were induced. Any efforts to reduce repeat CS should be viewed with fresh zeal which are promoting TOLAC (Trail of labour after caesarean), proper case selection, intensive monitoring and dedicated staff. Group 6 and 7 (breech presentation) includes 5.4\% of all deliveries, CS rate in group 6 was $77.5 \%$ and in group 7 was $66.6 \%$ (Table 3 ). However, Sneha et al have noted $100 \%$ CS rate in breech presentations. ${ }^{15}$ Similarly Samba et al has recommended increase use of ECV for breech presentations and conduct of vaginal breech deliveries. $^{16}$

Group 8 (Multiple pregnancy) comprises of $2.1 \%$ of all deliveries and CS rate in this group was $57.1 \%$. Group 9 (Singleton, transverse or oblique) consists of $0.5 \%$ of all deliveries and CS rate in this group was $100 \%$ (Table 3 ). Group 10 consists of $10.5 \%$ of all the deliveries, this is due to the fact that it is a tertiary care centre and patients with high risk of preterm labour are being referred here. CS rate in this group was $18.9 \%$. Best way to reduce the overall CS rate is by preventing the first CS, it is thus suggested that improved case selection for labour induction and pre labour caesarean section can reduce CS rates. VBAC and breech vaginal birth should be done wherever feasible and appropriate.

Main advantage of Modified Robson's classification is its simplicity, robustness, reproducibility and flexibility. It is clinically relevant and suitable even for low resource setting. Indication based CS classification are variable, subjective, lack clarity, deficient of relevant obstetric history and thus does not allow valid comparisons. Limitation of this study were that it does not allow analysis of CS by demand and those for specific indication like placenta previa. It does not account for preexisting medical, surgical condition or fetal distress, indication and methods used for IOL and degree of prematurity, all of which may influence the rate of CS. Group 5 include 2 different groups those who planned or needed repeat CS and those who attempted VBAC and required $\mathrm{CS}$.

\section{CONCLUSION}

Modified Robson's classification is easily implementable, can be effectively utilized in analysing delivering women and determinate contributors to caesarean sections to guide the health care providers to form strategies to avoid unnecessary sections.

\section{Funding: No funding sources \\ Conflict of interest: None declared \\ Ethical approval: Not required}

\section{REFERENCES}

1. Von Roosenmalen J, Van der Does CD. Caesarean birth rate worldwide. A search for determinants. Trop Geogr Med.1995;47(1):19-22.

2. World Health Organization. Appropriate technology for birth. Lancet. 1985;326(8452) 436-7.

3. Kambo I, Bedi N, Dhillon BS, Saxena NC. A Critical appraisal of cesarean section rates at teaching hospitals in India. Int $\mathbf{J}$ Gynaecol Obstet. 2002; 79(2):151-8.

4. Sreevidya S, Sathiyasekaran BW. High Cesarean rates in Madras (India): a population based crosssectional study. BJOG. 2003;110(2):106-11.

5. Robson M, Murphy M, Byrne F. Quality assurance: The 10-group classification system (Robson classification), induction of labour and caesarean delivery. Int J Gynecol Obstet. 2015;131(1):S23-27.

6. SOGC Committee Opinion. Classification of Caesarean section in Canada: The Modified Robson Criteria. J Obstet Gynaecol Can.2012;34(10):976-9.

7. Betran AP, Vindevoghel N, Souza JP, Gulmezoglu AM, Torloni MR. A systematic review of the Robson classification for caesarean section: what works, doesn't work and how to improve it. PloS One. 2014;9(6):e97769

8. Jacob KJ, Megha Jayaprakash, Hibina K.P. TMC (Thrissur Medical College) modified Robson criteria for caesarean sections. Int $\mathrm{J}$ Reprod Contracept Obstet Gynecol. 2017;6(11):5038-43.

9. Prameela RC, Farha A, Bhanumathi PM, Prajwal S. Analysis of caesarean section rate in a tertiary hospital according to Robson's ten group classification system. IOSR J Dent Med Sci. 2015; 14(2):46-9.

10. Kazmi T, Saiseema SV, Khan S. Analysis of caesarean section rate according to Robson's 10 group classification, Oman Med J. 2012;27(5):415-7.

11. Litorp H, Kidanto HL, Nystrom L, Darj E, Essén B. Increasing caesarean section rates among low-risk groups: a panel study classifying deliveries according to Robson at a university hospital in Tanzania. BMC Pregnancy and Childbirth. 2013;13(1):107.

12. Tanaka K, Mahomed K. The Ten-Group Robson Classification: A single centre approach identifying 
strategies to optimise caesarean section rates. Obstetrics and gynecology international. 2017;2017.

13. Shirsath A, Risbud N. Analysis of cesarean section rate according to Robson's 10-group classification system at a tertiary care hospital. Int J Sci Res. 2014; 3(1):401-2.

14. Kansara V, Patel S, Aanand N, Muchhadia J, Kagathra B, Patel R. A recent way of evaluation of cesarean birth rate by Robson's 10-group system. J Med Pharmaceut Allied Sci. 2014;1:62-70.

15. Dhodapkar SB, Bhairavi S, Daniel M, Chauhan NS, Chauhan RC. Analysis of caesarean sections according to Robson's ten group classification system at a tertiary care teaching hospital in south
India. Int J Reprod Contracept Obstet Gynecol. 2015;4(3):745-9.

16. Samba A, Mumuni K. A review of caesarean sections using the ten-group classification system in the Korle-Bu teaching hospital, Ghana. Gynaecol Obstet J. 2016;6(6).

Cite this article as: Dogra K, Arora N, Sharma B, Tanwar M. Analysis of caesarean section rate according to modified Robson's classification at tertiary care centre in Uttarakhand, India. Int J Reprod Contracept Obstet Gynecol 2019;8:1288-93. 